\title{
The Lacknau plantain: A high yielding cultivar with field resistance to the corm weevil, Cosmopolites sordidus (Germar) ${ }^{1,2}$
}

\author{
Héber Irizarry, Edmundo Rivera, José A. Rodriguez, \\ Isabel Beauchamp de Caloni and Domingo Oramas ${ }^{3}$
}

\begin{abstract}
Five Lacknau plantain clones were tested in the field against yellow sigatoka (Mycosphaerella musicola), the corm weevil (Cosmopolites sordidus) and nematodes (Radopholus similis), and for yield and fruit processing quality. These plantains retained 10 or more functional leaves even without a foliar spraying program at bunch-shooting. At harvest, however, the number of useful leaves was drastically reduced. This condition was not fotally related to sigatoka damage but to a rather faster rate of senescence occurring in unsprayed as well as sprayed leaves. These clones, without soil granular pesticides, recorded 4.5 cavities per rhizome and yielded 51.6 t/ha of fruits, 11 to 23 t/ha more than Maricongo in the plant crop. The application of carbamale based insecticide-nematicide compounds to corm weevil-resistant plantains reduced insect damage but did nol increase yields. All Lacknau clones were susceptible to the burrowing nematode. Fried flattened slices and chips prepared from Lacknau mature green fruits were rated as acceplable. However, $59 \%$ of the tasters preferred fried slices from Lacknau over those of Maricongo, and $90 \%$ chose the Maricongo chips.
\end{abstract}

\section{RESUMEN}

Lacknau: un cultivar de plátano4 de alto rendimiento con resistencia natural al picudo negro, Cosmopolites sordidus (Germar)

Se establecieron dos experimentos de campo en la subestación de Corozal para evaluar la resistencia de 5 clones del plátano Lacknau a la sigatoka amarilla (Mycosphaerella musicola), al picudo negro (Cosmopolires sordidus) y al nematodo barrenador (Radopholus similis) y para evaluar su potencial de rendimiento y la calidad de la fruta frita. En las pruebas se usaron el cultivar Maricongo y el plátano del pseudotallo

'Manuscript submitted to Editorial Board 30 April 1987.

${ }^{2}$ This paper covers work carried out cooperatively between the Agricultural Research Service-USDA, and the Agricultural Experiment Station, University of Puerto Rico, Rio Piedras, P. R.

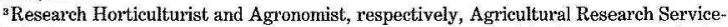
USDA; Associate Agronomist, Associate Food Technologist, and Assistant Nematologist, respectively, Agricultural Experiment Station, University of Puerto Rico, Río Piedras, P. R.

Musa acuminata $\times$ M. balbisiana (AAB). 
morado para compararlos. En el primer experimento los plátanos se cultivaron sin aspersiones contra la sigatoka común. Los clones de Lacknau tenían 10 o más hojas funcionales al florecer, pero al cosecharlos tenían mucho menos hojas que el cultivar Maricongo. Esta pérdida de hojas no se atribuyó totalmente al daño de la sigatoka sino a la aparente senescencia acelerada que sufre este cultivar después de florecer. En la segunda prueba los platanales se asperiaron, pero no se le aplicaron plaguicidas granulados al suelo. Las introducciones de Lacknau arrojaron una media de $\mathbf{4 . 5}$ cavidades por rizoma; los testigos arrojaron $\mathbf{2 0} 6$ más. Todas las introduceiones del plátano Lacknau fueron susceptibles al nematodo barrenador. Los clones Lacknau sin tratar produjeron una media de $51.6 \mathrm{Tm}$. ha. de frutas con rendimientos de 11 a $23 \mathrm{Tm}$./ha. más que el Maricongo. Las aplicaciones de plaguicidas granulados a los clones resistentes af picudo negro no reflejaron aumentos en rendimiento. Sin embargo, aldicarb $10 \mathrm{G}$ redujo aún más el daño del insecto con una media de 1.6 cavidades por rizoma. Los tratamientos con insecticida-nematicida granulados en cultivares de plátano susceptibles al picudo negro redujeron drásticamente el número de cavidades por rizoma y aumentaron los rendimientos, pero las diferencias en producción no fueron estadísticamente significativas. La fruta verde del plátano Lacknau demostró fener potencial para freir tostones, pero para platanutre, ${ }_{s}^{5}$ es cuestionable.

\section{INTRODUCTION}

All plantain cultivars and clones commercially grown in Puerto Rico are subjected to three major pathological problems: yellow sigatoka (Mycosphaerella musicola), the corm weevil (Cosmopolites sordidus) and the burrowing nematode (Radopholus similis).

Fairly high yields are usually obtained in the plant crop with the implementation of pesticide programs. However, these control measures are expensive, difficult to perform on hilly lands and prone to contaminating the environment. Although the sigatoka control program in Puerto Rico is subsidized by the local Department of Agriculture at a minimal cost to the growers, about $18 \%$ of the production cost is used in the chemical control of both the corm weevil and nematodes. Therefore, if plantains with field resistance to these organisms are selected, production cost can be reduced. Perhaps this important food erop can feasibly be grown in tropical areas where similar problems occur, but where growers cannot afford to use chemical control.

Various attempts have been made to identify and secure sources of diseases and pest resistance in the Musaceae family. Vakili (13) screened 186 edible triploid (AAA) banana eultivars and reported that $26 \%$ of the selections were resistant or tolerant to the attack of the yellow sigatoka pathogen. Pérez et al. (5) found that resistance to leaf spot diseases in plantains and bananas is closely associated with the genomic composition of the various taxonomic groups. On the assumption that plantains originated from a cross between the species Musa acuminata $\times M$. bal-

Tostón-rodaja frita y aplastada; platanutre-rodajas bien finas, fritas y saladas. 
bisiana, resistance increases in direct proportion to the percentage of germplasm from Musa balbisiana (BB) present in the cultivar or clone.

Haddad et al. (3) reported that the degree of infestation or damage by the corm weevil larvae also varied according to the genomic constitution of the individuals in the various taxonomic groups. Cultivars and clones of the $A B B$ group exhibited a low infestation index as compared to those of the $\mathrm{AAB}$ group. On the other hand, the comparison between bananas (AAA group) with either $\mathrm{AAB}$ or $\mathrm{ABB}$ plantains demonstrated that those individuals belonging to the former genomic group had a better chance to withstand an attack from soil-borne insects. Mesquita et al. (4) found that resistance or susceptibility in the Musa sp. to $C$. sordidus was not confined to a particular genomic group, but that it varied between and within groups. However, in this study the ABB group was represented by only one cultivar, which in fact was associated with reduction in pupal weight and increased mortality rate, two of the parameters used to determine resistance or susceptibility.

Information on sources of resistance to nematodes in plantains is scarce. Santor and Davide (11) attempted to screen plantain and banana cultivars against Radopholus similis and Meloidogyne incognita, and reported that the Saba $(A B B)$ plantain was susceptible to both nematode species. However, resistance to bacterial and fusarial pathogens which attack the plant vascular system has been identified in the Bluggoe ABB plantain by Stover and Richardson (12).

If multiple field resistance to the corm weevil and nematodes is not possible in plantains, the application of pesticides with insecticidal-nematicidal activity might further reduce damage in resistant cultivars. Román et al. (7) obtained effective control of $C$. sordidus and $R$. similis in susceptible plantains with periodic applications of carbamate-based insecticide-nematicide compounds.

The purpose of this study was to evaluate five Lacknau plantain clones in terms of resistance to yellow sigatoka, the corm weevil, and nematodes under field conditions, and to determine their yielding capacity and fruit processing characteristics.

\section{MATERIALS AND METHODS}

Twenty-one plantain clones were introduced from the Tropical Agriculture Research Services (SIATSA), La Lima, Honduras, in 1975 and subjected to a preliminary evaluation. Five clones were selected on the basis of apparent field tolerance to leaf spot diseases and soil-borne insects, and for their high yielding capacity and individual fruit size. These clones exhibiting similar plant, bunch, and fruit characteristics were originally introduced into Honduras from the Philippines, Sabah and Iranian Java. The clones were named Lacknau AVP-66, Lacknau II-22, Pisang Kalapeh II-121, Pisang Ruti II-192 and Dare III-30 (8) but locally were 
identified with the following P.I. numbers: 23464, 23472, 23475, 23476, and 23479 , respectively.

The plants are medium tall, ranging from 3.0 to $3.4 \mathrm{~m}$ with a fairly thick pseudostem diameter of 17 to $19 \mathrm{~cm}$. The foliage is pale-green and heavily waxed. Suckers are abundant and uniformly distributed around the base of the trunk.

These plantains produce French-type bunches (persistance of the flower male bud attached to the bunch rachis) or have an indeterminate infloreseence with 4 to 6 hands, averaging 15 and 14 fruits in the first and second hands, respectively. When $3 / 4$ full, fruit in the top hands were 22 to $28 \mathrm{~cm}$ long with 3.5 to $4.5 \mathrm{~cm}$ diameter. The fruit cross-section shape is somewhat angular ending in a blunt apex. The mature green fruits have a thin peel with a smooth outer skin and a relatively soft texture. When ripe, the pulp turns pale-yellow. According to Valmayor et al. (14), the Lacknau plantain is classified in the AAB Musa group, but in many of the plant, bunch and fruit morphological traits it resembles the ABB plantain.

Two experiments were established at the Corozal Substation from March 1979 through July 1983 to evaluate these promising plantain clones for field resistance to the yellow sigatoka $(M$. musicola $)$, the corm weevil (C. sordidus), the burrowing nematode ( $R$. similis), and for yield and fruit processing characteristics. The commercially grown horn-type Maricongo plantain and the red-pseudostem cultivar were used as susceptible varieties.

The Corozal Substation is located in north-central Puerto Rico at an elevation of about $200 \mathrm{~m}$ with a mean monthly rainfall of $137.5 \mathrm{~mm}$, and with average minimum and maximum air temperatures of 19 and $30^{\circ} \mathrm{C}$, respectively.

The soil is a deep-red Corozal clay (Aquic Tropudults) with $\mathrm{pH} 5.0$, containing $6.9 \mathrm{p} / \mathrm{m}$ of "available" P (Bray II method), and 0.3, 2.2 and 7.8 meq of exchangeable $\mathrm{K}, \mathrm{Mg}$ and $\mathrm{Ca} / 100 \mathrm{~g}$ of soil, respectively. The soil was plowed twice.

All plots received the equivalent of $3,150 \mathrm{~kg} / \mathrm{ha}$ of a $10-5-30-5(\mathrm{~N}$, $\mathrm{P}_{2} \mathrm{O}_{5}, \mathrm{~K}_{2} \mathrm{O}, \mathrm{MgO}$ ) fertilizer supplemented with $23 \mathrm{~kg} / \mathrm{t}$ of fritted micronutrients. This fertilizer was divided into equal portions and applied at 1,4 , 7 and 10 months after planting.

During occasional dry spells irrigation was applied at the rate of 40 $\mathrm{mm}$ every 2 weeks. Weeds were suppressed with post-emergence applications of either glyphosate [N-(phosphonomethyl) glycine (isopropy]amine) salt] or paraquat (1,1-dimethyl-4,4-bipyridinium ion) at the rates of 1 to $2 \%$ and 2.5 to $5 \mathrm{~L} / \mathrm{ha}$, respectively. ${ }^{6}$

Trade names in this publication are used only to provide specific information. Mention of a trade name does not constitute a warranty of equipment or materials by the Agriealtural Experiment Station of the University of Puerto Rico, nor is the mention a statement of preference over other equipment or materials. 
In the 1979-80 experiment, five Lacknau clones and the horn-type Maricongo cultivar were arranged in a randomized complete block design with 6 replieations and field tested for resistance against the yellow sigatoka disease. Each replication consisted of 6 plants spaced at $2.1 \times$ $1.8 \mathrm{~m}$, approximately 2,645 plants/ha. No attempt was made to spray the plant canopy, including those of the susceptible Maricongo. To minimize possible corm weevil and nematode damage, we applied ethoprop 10G (O-ethyl S,S-dipropyl phosphorodithioate) at the rate of $56 \mathrm{~g} / \mathrm{stump}$ every 4 months.

The 1982-83 experiment was designed to study the degree of field resistance of four Lacknau plantain clones to the corm weevil and the burrowing nematode with Maricongo and the red-pseudostem plantain as test cultivars. A secondary objective was to determine the effectiveness of aldicarb 10G [2-methyl-2 (methylthio) propionaldehyde 0-(methyl-carbamoyl) oxime] and carbofuran 10-G (2,3 dihydro-2,2-dimethyl-7-benzofuranyl-methyl-carbamate) in subduing insect and nematode damage in resistant and susceptible plantains at the recommended rate of $28 \mathrm{~g} /$ stump every 4 months.

The treatments were arranged in a split-plot experiment with clones and cultivars as the main plots and granular pesticide formulations and a control as the subplots. The main plots contained 18 plants spaced at $1.8 \times 1.8 \mathrm{~m}$, about 3,000 plants $/ \mathrm{ha}$, and replicated 6 times in a randomized complete block design.

Six months after planting and every 2 weeks thereafter all plants were sprayed with chlorothalonile (tetrachloro- isophthalonitrile) at the rate of $3 \mathrm{~L}$ /ha.

In both experiments the male bud inflorescence and the false hand were removed from all bunches at the time of flowering. Numbers of functional leaves were recorded at this stage and at harvest.

Bunches were harvested about 110 days after flowering and the weight and number of hands and fruits/bunch recorded. Fruit samples from the first experiment were sent to the Food Technology Laboratory of the Agricultural Experiment Station for chemical analyses, sensorial evaluations of fried flattened slices and chips, and other appraisals. The procedures in these studies have been described by Cancel et al. (1), González et al. (2), and Sánchez-Nieva et al. (9).

After harvest, the pseudostems were cut at ground level and the number of cavities per rhizome was recorded to a maximum of 20 tunnels/ stump. In the second experiment, nematode populations were studied in root and soil samples.

All recorded data were statistically analyzed and differences between means were accepted at least at the $5 \%$ level of probability according to Duncan's Multiple Comparison Test. 


\section{RESULTS AND DISCUSSION \\ Experiment No, 1, 1979-80}

Table 1 shows field performance of French-type Lacknau and horntype Maricongo plantains grown without a spraying program for the control of yellow sigatoka, but with application of granular pesticides against the corm weevil and nematodes. Except for clone 23472, all other plantains averaged 10 functional leaves at the time of bunch-shooting. At harvest, however, only the Maricongo cultivar retained more functional leaves than the Lacknau clones. This rapid deterioration of the foliage in the Lacknau plantains was not caused by an outbreak of the disease but by premature foliar senescence occurring in these clones.

Table 2 presents yields of plantains grown without a sigatoka control program. Lacknau clones 23475 and 23476 yielded the most: an average of 164,514 fruits, weighing 37 t/ha. Although these clones produced about 6.5 tha more than the local Maricongo cultivar, the differences were not statistically significant. In terms of food production, however, this increase in yield is equivalent to $2,600,000 \mathrm{cal} / \mathrm{ha}^{7}$

Lacknau clones produced the larger bunches; they averaged 77 fruits weighing $17.5 \mathrm{~kg}$, but the Maricongo individual fruits were heavier: an average of $318 \mathrm{~g} /$ fruit (table 2 ).

\section{Experiment No. 2, 1982-83}

Table 3 presents the field evaluation of French-type Lacknau introductions and horn-type commercial plantain cultivars grown without insecticide-nematicide applications but with a standard spraying program against foliar diseases. Lacknau clones evidenced significant fewer

TABLE 1.-Field perfommane of five Lacknau plantain clones and two hom-type cultivars groton with and without a yellow sigatoka eontrol program at the Conozal Substation

\begin{tabular}{ccccc}
\hline & \multicolumn{2}{c}{$\begin{array}{c}\text { Unsprayed canopy } \\
\text { Experiment No. 1, 1979-80 } \\
\text { Functional leaves at: } \\
\text { Clone } 0 \text { r cultivar }\end{array}$} & $\begin{array}{c}\text { Sprayed canopy } \\
\text { Experiment No. 2, 1982-83 } \\
\text { Functional leaves at: }\end{array}$ \\
\hline P.I. No. 23472 & No. & No. & No. & Ho. \\
23479 & $11.1 \mathrm{a}^{\mathrm{i}}$ & $4.9 \mathrm{~b}$ & $14.8 \mathrm{a}$ & $6.0 \mathrm{~b}$ \\
23464 & $10.4 \mathrm{~b}$ & $3.4 \mathrm{c}$ & - & - \\
23475 & $10.3 \mathrm{~b}$ & $4.2 \mathrm{bc}$ & $14.2 \mathrm{a}$ & $5.8 \mathrm{~b}$ \\
23476 & $10.3 \mathrm{~b}$ & $4.5 \mathrm{bc}$ & $14.5 \mathrm{a}$ & $6.1 \mathrm{~b}$ \\
Maricongo & $10.1 \mathrm{~b}$ & $4.3 \mathrm{bc}$ & $14.8 \mathrm{a}$ & $6.1 \mathrm{~b}$ \\
Red-pseudostem & $10.1 \mathrm{~b}$ & $6.3 \mathrm{a}$ & $12.7 \mathrm{~b}$ & $6.9 \mathrm{a}$ \\
& - & - & $12.2 \mathrm{~b}$ & $7.4 \mathrm{a}$ \\
\hline
\end{tabular}

'Means followed by the same letters do not differ significantly at the $\mathrm{P}=0.05$ probability level.

${ }^{7} 1 \mathrm{~kg}$ of dry plantain fruit pulp contains about 1,650 calories. 
TABLE 2.-Yieldiha, number of fruits and weightibunch and mean fruit weight obtained from five Lacknau plantain olones and the Maricongo cultivar grown without a foliar spray fungicide to control yellow sigatoka, Experiment No, 1, 1979-80

\begin{tabular}{|c|c|c|c|c|c|}
\hline \multirow{2}{*}{$\begin{array}{c}\text { Clone } \\
\text { or eultivar }\end{array}$} & \multicolumn{2}{|c|}{ Production/ha } & \multicolumn{2}{|c|}{ Production/bunch } & \multirow{2}{*}{$\begin{array}{l}\text { Mean weigh } \\
\text { of fruits }\end{array}$} \\
\hline & Fruits & Weight & Fruits & Weight & \\
\hline & No. & $t$ & No. & $k g$ & $g$ \\
\hline P.I. 23475 & $172,031.3 \mathrm{a}^{1}$ & $37.6 \mathrm{a}$ & $81.2 \mathrm{ab}$ & $17.6 \mathrm{a}$ & $221.7 \mathrm{~b}$ \\
\hline 23476 & $156,995.9 \mathrm{a}$ & $36.5 \mathrm{a}$ & $76.7 \mathrm{ab}$ & $17.8 \mathrm{a}$ & $233.1 \mathrm{~b}$ \\
\hline 23472 & $132,221.7 \mathrm{ab}$ & $81.5 \mathrm{ab}$ & $74.7 \mathrm{~b}$ & $17.6 \mathrm{a}$ & $238.4 \mathrm{~b}$ \\
\hline 23464 & $123,593.4 \mathrm{abc}$ & $27.4 \mathrm{ab}$ & $82.8 \mathrm{a}$ & $18.2 \mathrm{a}$ & $223.2 \mathrm{~b}$ \\
\hline 23479 & $101,125.8 b c$ & $25.4 \mathrm{~b}$ & $69.1 \mathrm{c}$ & $16.7 \mathrm{a}$ & $244.8 \mathrm{~b}$ \\
\hline Maricongo & $91,258.8 c$ & $30.5 \mathrm{ab}$ & $42.1 \mathrm{c}$ & $13.7 \mathrm{~b}$ & $317.8 \mathrm{a}$ \\
\hline
\end{tabular}
level.

1.Means followed by the same letters do not differ significantly at the $\mathrm{P}=0,05$ probability

cavities per plant rhizome than Maricongo and the red-pseudostem cultivar. A differential reaction to the corm weevil attack was detected among Lacknau plantains: clones 23464,23472 and 23475 were highly tolerant with fewer cavities per rhizome.

There were no significant differences in number of $R$. similis in roots among Lacknau clones and the Maricongo cultivar. However, there were significantly fewer $R$. similis in the red-pseudostem cultivar than in two clones of Lacknau: 23475 and 23476 (table 3). In the Dominican Republic, this is the predominant cultivar found in ratoon fields that have been under cultivation for 20 to 25 years. ${ }^{8}$

All sprayed plantains had more functional leaves than the nonsprayed (table 1). As in the first experiment, at the time of bunch-shooting, Lacknau clones had signifieantly more functional leaves than the

TABLE 3.--Evaluation of four Lacknau introductions and two commercial plantain cultivars for $\mathbf{C}$. sordidus and $\mathbf{R}$. similis damage on the basis of number of tunnelstrhizome and nematode larvae recovered from roots and soil samples of untreated plants after completion of the plant crop harvest, Experiment No, 2, 1982-83

\begin{tabular}{cccc}
\hline & & \multicolumn{2}{c}{ Nematode larvae in: } \\
\cline { 3 - 4 } Clone or eultivar & Tunnelsirhizome & 25 gof root tisoue & $250 \mathrm{mg}$ of soil \\
\hline & $3.1 \mathrm{a}^{\mathrm{s}}$ & $804 \mathrm{~b}$ & No. \\
P.I. No. 23475 & $3.8 \mathrm{a}$ & $231 \mathrm{ab}$ & $27 \mathrm{a}$ \\
23472 & $3.8 \mathrm{a}$ & $324 \mathrm{ab}$ & $27 \mathrm{a}$ \\
23464 & $7.5 \mathrm{a}$ & $1,857 \mathrm{~b}$ & $160 \mathrm{a}$ \\
23476 & $19.4 \mathrm{~b}$ & $457 \mathrm{ab}$ & $133 \mathrm{a}$ \\
Maricongo & $19.7 \mathrm{~b}$ & $44 \mathrm{a}$ & $187 \mathrm{a}$ \\
Red-pseudostem & & $53 \mathrm{a}$
\end{tabular}
level.

${ }^{1}$ Means followed by the same letters do not differ significantly at the $\mathrm{P}=0.05$ probability

"Irizarry, H. Personal communication. 
TABLE 4.-Yield performance, bunch attributes, and mean fruit weight obtained from four Lacknau clones and two commercial cultivars grown without soil-applied pesticides, Experiment No. 2, 1982-83

\begin{tabular}{|c|c|c|c|c|c|c|}
\hline \multirow[b]{2}{*}{ Clone or cultivar } & \multicolumn{2}{|c|}{ Production/ha } & \multicolumn{3}{|c|}{ Production/ounch } & \multirow{2}{*}{$\begin{array}{l}\text { Mean weight } \\
\text { of fruits }\end{array}$} \\
\hline & Fruits & Weight & Hands & Fruits & Weight & \\
\hline & No. & $t$ & No. & No. & $\mathrm{kg}$ & $g$ \\
\hline P.I. No. 23476 & $228,343.8$ a & $59.1 \mathrm{a}$ & $5,6 \mathrm{e}$ & $88.2 \mathrm{a}$ & $22.7 \mathrm{a}$ & $258 \mathrm{ab}$ \\
\hline 23472 & $208,286.2$ a & $51.6 \mathrm{ab}$ & $6.2 \mathrm{bc}$ & $92.9 \mathrm{a}$ & $22.5 \mathrm{a}$ & $243 b$ \\
\hline 23464 & $202,057.2 \mathrm{a}$ & $48.9 \mathrm{ab}$ & $6.4 \mathrm{~b}$ & $95.3 \mathrm{a}$ & $22.8 a$ & $241 \mathrm{~b}$ \\
\hline 23475 & $196,201.8 \mathrm{a}$ & $46.6 \mathrm{ab}$ & $5.7 \mathrm{c}$ & $87.6 \mathrm{a}$ & $20.9 \mathrm{a}$ & $239 \mathrm{~b}$ \\
\hline Maricongo & $120,207.2 \mathrm{~b}$ & $36.0 \mathrm{bc}$ & $7.1 \mathrm{a}$ & $53.2 \mathrm{~b}$ & $15.6 \mathrm{~b}$ & 294 a \\
\hline Red-pseudostem & $98,098.1 \mathrm{~b}$ & $26.8 \mathrm{c}$ & $7.1 \mathrm{a}$ & $54.3 \mathrm{~b}$ & $14.9 \mathrm{~b}$ & $280 \mathrm{ab}$ \\
\hline
\end{tabular}
level.

${ }^{1}$ Means followed by the same letters do not differ significantly at the $\mathrm{P}=0.05$ probability

commercial cultivars, but thereafter, leaf senescence developed at a faster rate in the Lacknau clones.

Table 4 presents yields obtained from insecticide-nematicide untreated plantains. Under these conditions Lacknau clones demonstrated a higher yielding capacity than the Maricongo and the red-pseudostem cultivars. Lacknau clones produced an average of 208,722 fruits or 51.6 tha; commercial varieties an average of $\mathbf{1 0 6 , 6 5 3}$ fruits and $31.4 \mathrm{t} / \mathrm{ha}$. Clone 23476 produced the most: 228,344 fruits or 59.1 t/ha.

French-type Lacknau clones produced larger bunches than the horntype commercial cultivars; they averaged 91 fruits and $22.2 \mathrm{~kg} / \mathrm{bunch}$ (table 4). However, horn-type varieties produced heavier fruits averaging $287 \mathrm{~g}$.

Performance of granular insecticides in corm weevil resistant and susceptible plantains

Applications of either aldicarb $10 \mathrm{G}$ or carbofuran $10 \mathrm{G}$ formulations to Lacknau clones further reduced the average number of tunnels per rhizome in corm weevil resistant plantains, (fig. 1-A), but only the aldicarb $10 \mathrm{G}$ treatment was significantly more effective than the control, with fewer than 2 cavities/rhizome. However, applications of these compounds failed to increase yields over that of the resistant control.

The use of granular insecticide-nematicide compounds in corm weevil susceptible cultivars effectively reduced insect damage in these plantains. Aldicarb $10 \mathrm{G}$ was the most promising compound with 5 eavities/ rhizome (fig. 1-B). Average yields obtained from susceptible control, carbofuran $10 \mathrm{G}$, and aldiearb $10 \mathrm{G}$ treatments were $30.5,34.1$ and $39.8 \mathrm{t} / \mathrm{ha}$ of fruits, respectively, but the differences were not statistically significant.

In addition to the desirable characteristics recorded in the Lacknau plantain, no fruit "cigar-end tip rot" has been observed, a condition com- 
TABIE 5.-Chemical composition and other eharacteristies in the mature-green frut of the Lacknau plantain, Eaperiment No. 1, 1979-80

\begin{tabular}{lc}
\hline \multicolumn{1}{c}{ Characteristic } & Content \\
\hline $\mathrm{pH}$ & 5.60 \\
Total acidity as anhydrous citric acid & .15 \\
Reducing sugars & $.46 \%$ \\
Total sugars as invert & $.51 \%$ \\
Starch & $28.50 \%$ \\
Peel & $38.40 \%$ \\
Pulp & $61.60 \%$ \\
Pulp:peel ratio & 1.62 \\
Texture (shear press force) & $508.03 \mathrm{~kg}$ \\
\hline
\end{tabular}

monly associated with Verticillium theobromae and Deightoniella torulosa fungi. Both locally grown plantain cultivars, Maricongo and Common Dwarf, are susceptible to this disease and the severity of the damage is closely related to high humidity conditions.

\section{Processed products}

The Lacknau plantains compared favorably with Maricongo and Guayamero cultivars (10) for chemical constituents at the same stage of maturity (table 5). In addition, the fruit is softer in texture and can be easily peeled by applying a hot water bath treatment at a temperature of $34^{\circ} \mathrm{C}$ for 20 minutes. No fruit stain was released during the hot water peeling treatment.

With regard to the sensorial appraisals, both fried flattened slices and chips prepared from Lacknau mature green fruits were classified as acceptable by tasting panels scoring a value of 1 or more in the hedonic scale (table 6). As to preference, $59 \%$ of the tasters preferred the fried slices obtained from the Lacknau plantains and $41 \%$ preferred the Maricongo cultivar. On the other hand, only $10 \%$ of the panelists favored

TABLE 6.-Ratings obtained in the sensorial evaluations of processed plantain products from Lacknau and Maricongo matare-green fruits

\begin{tabular}{lcccc}
\hline \multirow{2}{*}{$\begin{array}{c}\text { Cultivar } \\
\text { tasters }\end{array}$} & \multicolumn{3}{c}{ Appraisals and numerical values } \\
\cline { 3 - 5 } & & First & Second & Average \\
Lacknau & 21 & 1.3 & 1.2 & 1.3 \\
Maricongo & 21 & 1.2 & 0.8 & 1.0 \\
& 12 & & Fried chips & \\
Maricongo & 12 & 1.3 & 1.5 & 1.4 \\
Lacknau & 1.0 & 1.0 & 1.0 \\
\hline
\end{tabular}

${ }^{1}$ Hedonic scale $(6)$ in which $+2=$ very acceptable; $+1=$ acceptable, $0=$ doubtful, -1 $=$ lightly unacceptable, and $-2=$ unacceptable. 
the fried chips from the Lacknau fruits, whereas $90 \%$ preferred those processed from Maricongo. Other Lacknau fruit industrialized products with market potentials are the grated pulp and flour.

\section{LITERATURE CITED}

1. Cancel, L, E., M. A. González and F. Sánchez-Nieva, 1962. Elaboración de platanutre, Publ, 6, Food Technol. Lab. Agr. Exp. Stn., Univ. P. R., 18 pp.

2. González, M. A., E. Dłaz-Negrón and A. R. Sandoval, 1969. Studies on the stability of fried plantain chips. J. Agric. Univ. P. R. 53 (1): 67-74.

3. Haddad, O., J. S. Surga and M. Wagner, 1979. Relación de la composieión genómica de las Muséceas con el grado de atraceión de adultos y de larvas de Cosmopolites sordidus, G. (Coleopy Curculionidae), Agron. Trop. (Maracay, Venez.) 29 (5): 429 38.

4. Mesquita, A. L. M., J. Alves and R. C. Caldas, 1984. Resistance of banana cultivars to Cosmopolites sordidus (Germar). Fruits (France) 39 (4): 254-57.

5. Pérez, V. L., C. Torres and M. Delgado, 1982. Resistencía de diferentes clones de plátano (Musa sp.) a la Sigatoka causada por Mycosphaerella musicola, Agrotecnia de $C u b a 13$ (2): 51-66.

6. Peryam, D. R. and F. J. Pilgrim, 1957. Hedonie seale method of measuring food preferences. Food Technol. 11 (9): 9-14.

7. Román, J., X. Rivas, D. Oramas and J. A, Rodrígtuez, 1983. Control of nematodes and black weevils in plantains. J. Agric. Univ. P. R. 67 (3): 270-77.

8. Rowe, $P$. R., 1976. Possibilités d'amélionation genétique des rendements de plantain. Fruits (France) 31 (9): 581-36.

9. Sánchez-Nieva, F., G. Colom-Covas, L. Hernández, R. Guadalupe, N. Díaz and C. B. Vinas, 1968. Preharvest changes in the physieal and chemical properties of plantains. J. Agric. Univ. P. R. 52 (3): 241-55.

10. - I. Hernández, G. Colom-Covas, R. Guadalupe, N. Díaz and C. B. Viñas, 1968. A comparative study of some characteristics of two plantain cultivars which affect yields and products quality. J. Agric. Univ. P. R. 52 (4): $323-38$.

11. Santor, W. and R. G. Davide, 1982. Interrelationship of Radopholus similis and Meloidogyne incognita in banana. Philipp. Phytopathol. 18: 22-33.

12. Stover, R. H. and D. L. Richardson, 1968. Pelipita, an ABB Bluggoe type plantain resistant to bacterial and fusarial wilts. Plant Dis. Rep. 52: 901-08.

13. Vakili, N. G., 1968. Responses of Musa acuminata species and edible cultivars to infection by Mucosphaerella musicola. Trop. Agric. (Trinidad) 45 (1): 13-22.

14. Valmayor, R. V., F. N. Rivera and F. M. Lomuljo, 1981. Philippine banana eultivar names and synonyms. National Plant Genetic Resouree Laboratory, Institute of Plant Breeding, Univ, of Philipp. at Los Baños, Philipp. 
